\title{
Assessment of Drinking Water Quality in Umoja Innercore Estate, Nairobi
}

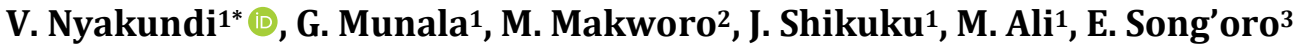 \\ ${ }^{1}$ Center for Urban Studies, Jomo Kenyatta University of Agriculture and Technology, Nairobi, Kenya \\ ${ }^{2}$ Department of Landscape Architecture, Jomo Kenyatta University of Agriculture and Technology, Nairobi, Kenya \\ ${ }^{3}$ Department of Medical Microbiology, Jomo Kenyatta University of Agriculture and Technology, Nairobi, Kenya \\ Email: *victor.nyakundi@jkuat.ac.ke
}

How to cite this paper: Nyakundi, V., Munala, G., Makworo, M., Shikuku, J., Ali, M. and Song'oro, E. (2020) Assessment of Drinking Water Quality in Umoja Innercore Estate, Nairobi. Journal of Water Resource and Protection, 12, 36-49.

https://doi.org/10.4236/jwarp.2020.121002

Received: November 12, 2019

Accepted: January 3, 2020

Published: January 6, 2020

Copyright (c) 2020 by author(s) and Scientific Research Publishing Inc. This work is licensed under the Creative Commons Attribution International License (CC BY 4.0).

http://creativecommons.org/licenses/by/4.0/

\begin{abstract}
Water quality is one of the main indicators of the quality of service provided to consumers. Quality has an impact on both the public health and aesthetic value of water as a consumable product. Kenya is classified as a water-scarce country with only 647 cubic meters of renewable freshwater per capita. Water distributed in Nairobi is faced with a myriad of challenges leading to a compromise to its quality. This study focused on evaluating quality of drinking water since human health depends on adequate, clean, reliable water. Analyses were carried out at National Environmental Management Authority (NEMA) accredited Jomo Kenyatta University of Agriculture and Technology (JKUAT) laboratories to determine the chemical, bacteriological and physical characteristics of consumed water in Umoja Innercore Estate in Nairobi. In the study area, $7 \mathrm{HH}$ and $6 \mathrm{BH}$ sites were randomly distributed. $\mathrm{pH}$, turbidity and temperature measurements were analyzed in-situ while bacteria and chemicals were analyzed in laboratories. The study found that $100 \%$ of boreholes recorded unsatisfactory water with up to 1100 of Escherichia coli (E. coii) showing high contamination with faecal coliforms and $83 \%$ of boreholes recording $\mathrm{pH}$ of up to 9.53. Dissolved oxygen was $5.08 \mathrm{mg} / \mathrm{L}$ below recommended $12.0 \mathrm{mg} / \mathrm{L}$, salinity of $0.47 \mathrm{mg} / \mathrm{L}$ and $0.03 \mathrm{mg} / \mathrm{L}$ for boreholes and households respectively. The study reveals the deprived quality of water available to the residents of Umoja Innercore, Nairobi. The study recommends the use of biosand filtration methods for septic tanks, digging of deeper boreholes and lining septic tanks with impermeable materials to prevent contamination of ground water with raw water from septic.
\end{abstract}

\section{Keywords}

Drinking Water Quality, Assessment, Quality Monitoring, Nairobi 


\section{Introduction}

Water quality assessment is key since water is the second most essential factor for the survival of human beings next to oxygen [1]. Safe drinking water and proper sanitation have constantly been recognized as indispensable factors to sustain life [2]. Consumption of contaminated water is a major cause of illness in the world and particularly in developing countries like Kenya [3]. According to [3], 2.6 billion people lack access to clean water and water-related diseases lead to 3.4 million deaths mostly in children every year [1]. According to United Nations Children's Fund (UNICEF) assessment, contaminated water leads to 4000 deaths in children each day. Global disease burden can be reduced approximately by $4 \%$ by improving water quality [1].

As reported by [1], water is indispensable for life. Urbanization, overpopulation, environmental pollution and ever increasing demand, pose a risk for the availability of safe drinking water. Safe drinking water is basic human right and prerequisite for healthy life [4]. However, there are many problems concerning drinking water supply and they are mostly in the distribution network, not at the production level and this is the missing link to maintain high quality standards.

Water's role in sustainable development is further emphasized in Sustainable Development Goal number 6 which advocates for safe access to water and sanitation for all. This simultaneously aims to improve water quality by reducing pollution and halving current levels of untreated wastewater, while substantially increasing recycling and safe water reuse [5].

According to [6] in its report, improperly treated sewerage and uncollected garbage have contributed to a vicious cycle of water pollution, water-borne diseases, poverty, and environmental degradation. Water pollution carries environmental and health risks to communities within Nairobi, especially the poor who may use untreated water due to high cost of clean drinking water.

It has been reported that residents in Nairobi County are consuming or may have been exposed to contaminated water, leading to an unprecedented increase in cases of diarrhea and water-borne diseases, including cholera [7].

Ndakaini, Ruiru, and Susumua dams are the principal sources of water for Nairobi. These dams are all on rivers emanating from the Aberdare Forest [6]. Several factors compromise the city's water quality, ranging from natural phenomena such as the high fluoride content in groundwater, to anthropogenic factors such as poor wastewater treatment and environmental degradation both within the city and in the surrounding countryside [6]. The drinking water of Nairobi City Water and Sewerage Company (NCWSC) treatment works at Ng'ethu is of good quality within acceptable World Health Organization (WHO) standards. However, in Umoja Innercore, one of the city's estates, clean water from NCWSC has become limited and is in scarcity forcing residents to rely on private distributors from boreholes whose quality cannot be ascertained.

Throughout Umoja Innercore estate, water shortage is evidenced by the presence of many private water distributors in form of water bowsers and water bo- 
reholes whose source is unknown and therefore quality uncertain. These constraints fall chiefly on the mismanagement of this available water which has had a direct effect on the quality supplied to households [8].

Although there has been a small overall improvement in quality management of drinking water in Nairobi, it's estimated that a majority of residents still lack access to quality drinking where the demand is very high. This study therefore addresses the gap of formulating frameworks of how private suppliers and households not just in Umoja but in other suburbs can reduce contamination to ensure quality standards are met in the distribution of drinking water as per Water Services Regulatory Board (WASREB) and WHO standards.

\section{Water Quality Parameters and Indicators}

Water quality measurement involves chemical, bacteriological and physical analysis that determines the "goodness" of water for particular purposes. As reported by WHO in its report on guidelines on water quality and effluent monitoring [9], "goodness" determination requires water quality tests that will give information about the health of the water. By testing water over a period of time, the changes in the quality of the water can be seen using parameters that include temperature, $\mathrm{pH}$, turbidity, salinity, nitrates and phosphates [10].

\subsection{Monitoring for Compliance}

According to [11], surveillance of drinking water supplies assesses the safety and acceptability of the water distributed to the public so that consumers are consistently and reliably protected from the health hazards of contaminated supplies.

To gauge the water quality in Kenya, the government has formulated guidelines through WASREB. The guidelines measure a number of parameters which include

1) Pathogenic organisms to be nil per $100 \mathrm{ml}$.

2) Containing no chemicals that have an adverse or long term effect on human health with a pH between $6.5-8.5$ units.

3) Clear (turbidity of not more than 5.0 Nephelometric Turbidity Units (NTU)).

4) Salinity of not more than $0.4 \mathrm{mg} / \mathrm{L}$.

5) Not causing an encrustation of the water supply system not staining clothes.

6) Biological Oxygen Demand (BOD) of not more than $12 \mathrm{Mg} / \mathrm{L}$.

7) Temperature range of between $15^{\circ} \mathrm{C}-30^{\circ} \mathrm{C}$.

8) Taste and odour-Shall not be offensive to consumers.

Each sample must be analyzed to ensure compliance with the Kenya Standards as set out in schedules $1-7$. Compliance is handled in two ways:

1) Number of tests conducted against number of samples planned according to guideline and

2) Number of samples within norm against number of samples tested (WASREB, 2008).

According to [12], surface water sources rarely meet these requirements 
without adequate treatment. The treatment processes here are those involving physical, chemical and bacteriological changes so as to transform the raw water to potable water [9]. The values of these parameters are harmful for human health if they occurred more than defined limits (WHO, 2012; BIS, 2012) [13].

\subsection{The Health of Drinking Water}

Total and Faecal Coliforms-Faecal Coliforms are naturally occurring bacteria found in the intestines of all warm blooded animals (including humans) and birds. The presence of Faecal Coliforms is an indicator of contamination by faecal matter [10]. Faecal Coliforms indicate a risk to human health. They are not pathogenic (disease causing) but indicate that pathogenic bacteria and viruses may be present [10].

E. coli-commonly regarded as one of first microorganisms of choice in water quality monitoring programs and serves as the primary indicator for water contaminated with faecal matter due to their prevalence in the gut of warm-blooded animals as well as high numbers excreted in both human and animal faeces [2].

Chemical attributes of a waterway can be important indicators of water quality. Chemical attributes of water can affect aesthetic qualities such as how water looks, smells, and tastes. Chemical attributes of water can also affect its toxicity and whether or not it is safe to use [13].

Physical attributes are the simplest indicators of water quality e.g. changes in temperature may indicate the presence of certain effluents, while changes in, turbidity, colour affect acceptability of water for drinking [13].

\section{Methodology}

This experimental research collected water from 13 sites distributed within Umoja Innercore Estate, Nairobi. It assessed quality through measuring the physical, chemical and bacterial parameters. The Physical water parameters included, colour, smell, taste and turbidity. The chemical parameters were Chlorine residual, $\mathrm{pH}$, Salinity and Dissolved Oxygen while the bacteria included total and faecal coliforms. Umoja Innercore estate is typical of high rise housing typologies. Its latitude and longitudes are $1.2843^{\circ} \mathrm{S}, 36.8923^{\circ} \mathrm{E}$. The estate is bound by a $25 \mathrm{~m}$ wide road known as Moi Drive. The distribution of the sampled sites are as shown in Figure 1 below which included Institution e.g. Hospital, churches, residential apartments and a private school.

\subsection{Data Collection Protocol}

Total samples collected were 13. (6 samples, one each from a boreholes and 7 samples each from a households). Sample from each borehole were collected using sterilized plastic bottles were used to collect water samples from each and taken to NEMA accredited JKUAT Medical Laboratory Science lab for analysis. The Following parameters were checked: Coliform Test, Turbidity, pH, Total Dissolved Oxygen and temperature. Three samples were drawn from each sampling 


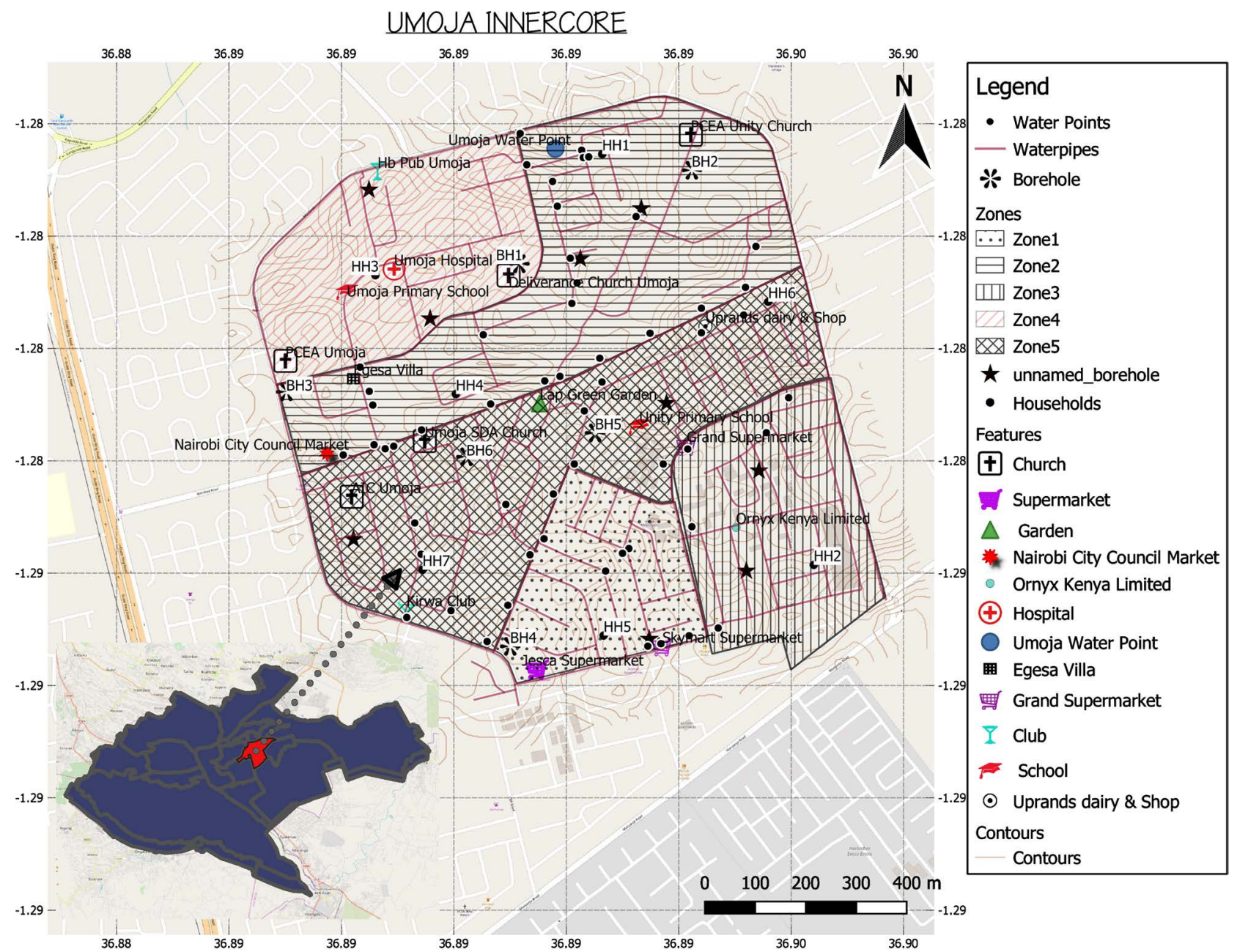

Figure 1. Sampling sites within study area.

point per zone within Umoja Innercore. Three control samples from the Phase 1 - 3 was drawn in triplicate from $\mathrm{Ng}$ 'ethu water treatment works in Kiambu County at the last point of treatment on the assumption that leaving treatment works was of good quality and lacking contamination. From each borehole, about $500 \mathrm{ml}$ of water sample from each source was collected in triplicate from a running tap. Temperature and $\mathrm{pH}$ measurements were taken on site using Hannas $\mathrm{pH}$ and Temperature meter, calibrated using a buffer a day before testing, thereafter bottles labeled and kept in a cool box during transportation and analyzed in the laboratory within 6 hours of collection to determine faecal coliforms (E. coli), dissolved oxygen, salinity as well as turbidity. The samples were tested within $6-8$ hours of collection [3]. The turbidity of each water sample was tested using the Portable Turbidity meter because it is more accurate, faster and precise. According to [3], the Turbidity was measured in NTU, with values below 5 NTU considered safe for drinking.

The Presumptive Test-About $1 \mathrm{ml}$ of raw water was also put in the single strength universal tubes resulting to 39 tubes and $0.1 \mathrm{ml}$ put into the single strength resulting to a further 39 tubes for 13 sampling bottles representing 6 bo- 
reholes and 7 households from the entire umoja innercore. This totalled to 117 bottles for presumptive test of bacterial examination. The Mac Conkey broth was then incubated at $37^{\circ} \mathrm{C}$ for 24 hours. Gas production and colour change in any of the tubes was a presumptive evidence of coliforms through faecal contamination.

The Confirmed Test-Out of the 117 tubes, 50 were positive. The 50 positive tubes were then inoculated in Mac Conkey agar plates with material from a tube containing gas and inverted and incubated the plate at $37^{\circ} \mathrm{C}$ for 24 hours. Mac Conkey agar media were prepared, observed the number of tubes at each dilution that showed the gas. Results were recorded and determined the most probable number index [14].

The Completed Test-The 27 samples of the MacConkey broth were positive. Colonies from the MacConkey agar media were then sub cultured on freshly prepared Nutrient agar media and incubated at $37^{\circ} \mathrm{C}$ for 24 hours to achieve rigorous growth of pure culture which was subjected to various biochemical tests Triple Sugar Iron (TSI), Simmon Citrate (SC), Tryptone water (TW), Buffered Glucose (BG) and Motility Media for bacterial identification [14].

\subsection{Interpretation of Results}

According to [9], Coliform count of 0 per $100 \mathrm{ml}$ is considered excellent. Range between 1 - 3 is Satisfactory, 4 - 10 Unsatisfactory and coliforms above 10 counts per $100 \mathrm{ml}$ considered suspicious.

\section{Results and Analysis}

The water quality assessment in Umoja Innercore Estate was done through analyzing the chemical, physical and bacteriological analysis. The bacteriological analysis focused on testing the presence of coliforms, the aim of the chemical analysis was to measure its toxicity and whether or not it is safe to use while the physical parameters measured the turbidity, colour, smell and taste.

\subsection{Chemical Examination of Water Sources}

The $\mathrm{pH}$ of the household water ranged from 6.67 to 7.87 . The recommended $\mathrm{pH}$ by WASREB is from 6.5 - 8.5 meaning drinking water should neither be acidic or alkaline. On the other hand, $100 \%$ of boreholes recorded a $\mathrm{pH}$ of above 7 with BH 3 recording the highest $\mathrm{pH}$ value of 9.53. As shown in Figure 2, BH 3 never treats water for chlorine citing high treatment costs of reagents required hence the high alkalinity of water.

Dissolved oxygen in Figure 3, shows HH1 recorded $8.73 \mathrm{mg} / \mathrm{L}$ of in water ac compared to BH 6 with $5.08 \mathrm{mg} / \mathrm{L}$. Recommended limit is $12 \mathrm{mg} / \mathrm{L}$. Low dissolved oxygen indicate high BOD hence more microorganisms in water. 100\% Borehole water has dissolved oxygen less than $6 \mathrm{mg} / \mathrm{L}$ hence higher BOD since microorganisms consume the oxygen.

As shown in Figure 4, good drinking water should have a maximum allowable salt concentration of $0.4 \mathrm{mg} / \mathrm{L}$. Salinity is often based on chloride concentration 


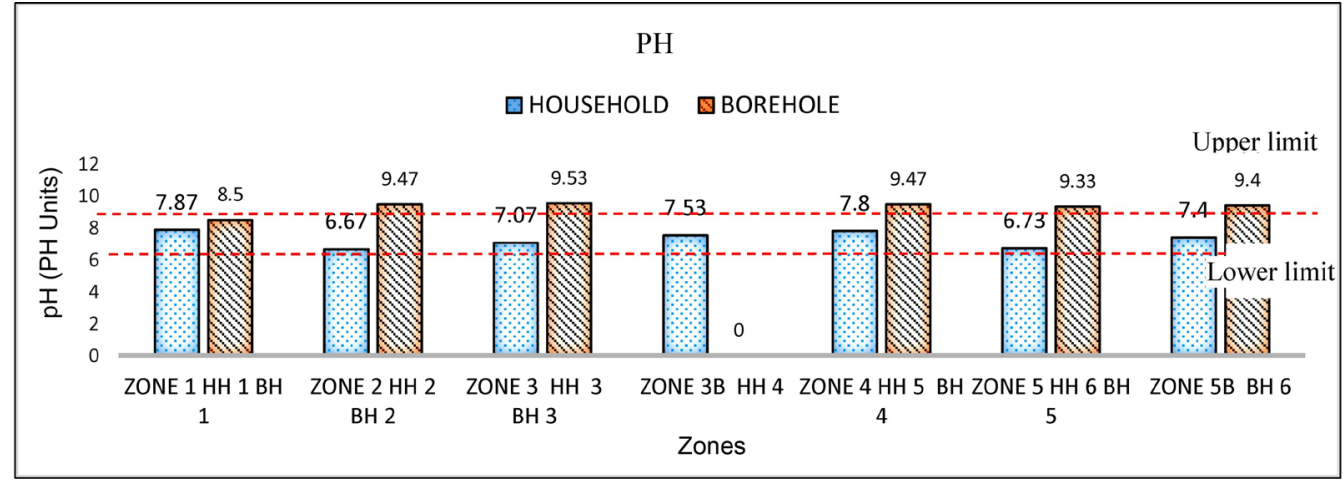

Figure 2. Graph showing $\mathrm{pH}$ measure of water samples.

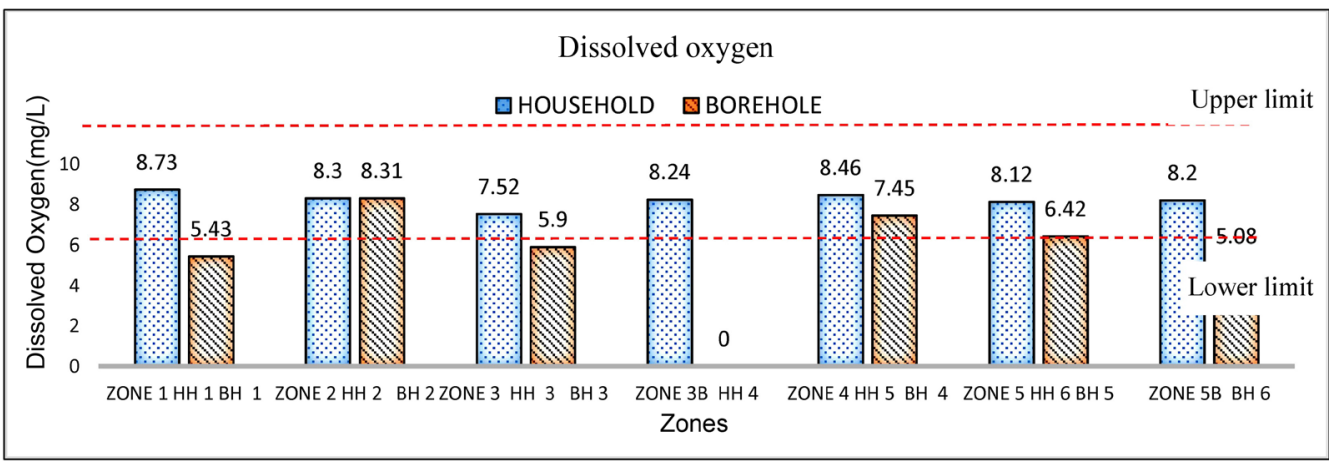

Figure 3. Dissolved oxygen concentration in water.

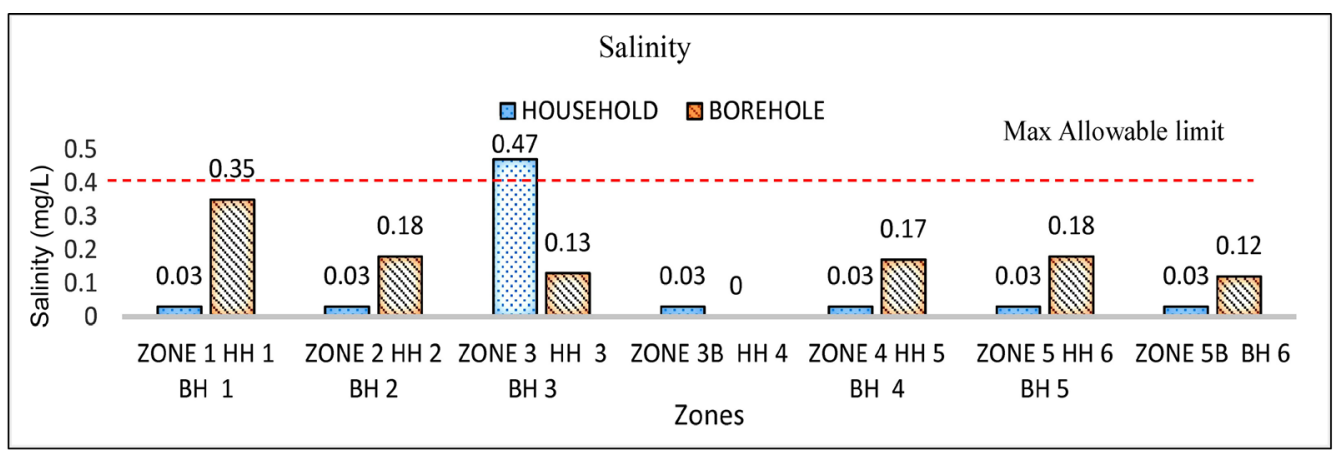

Figure 4. Salinity of drinking water.

and is a strong contributor to conductivity. The study revealed that $\mathrm{HH} 3$ indicated higher dissolved salt contents as compared to all boreholes and households' water recorded 0.03 . This household receives borehole water indicating presence of contamination of the borehole with salts or metals including magnesium, iron, copper, mercury etc. making the water unsafe for consumption.

Temperature is an indicator of quality since good drinking water should be at room temperature. Temperatures close to $37^{\circ} \mathrm{C}$ allow for bacteria to multiply making water unsafe for consumption since it's an optimum bacteria temperature. The solubility of oxygen decreases as the water temperature increases. From Figure 5, 86\% of boreholes recorded temperatures above $26^{\circ} \mathrm{C}$ while $100 \%$ of households' records were within range with the lowest being $19.97^{\circ} \mathrm{C}$. 


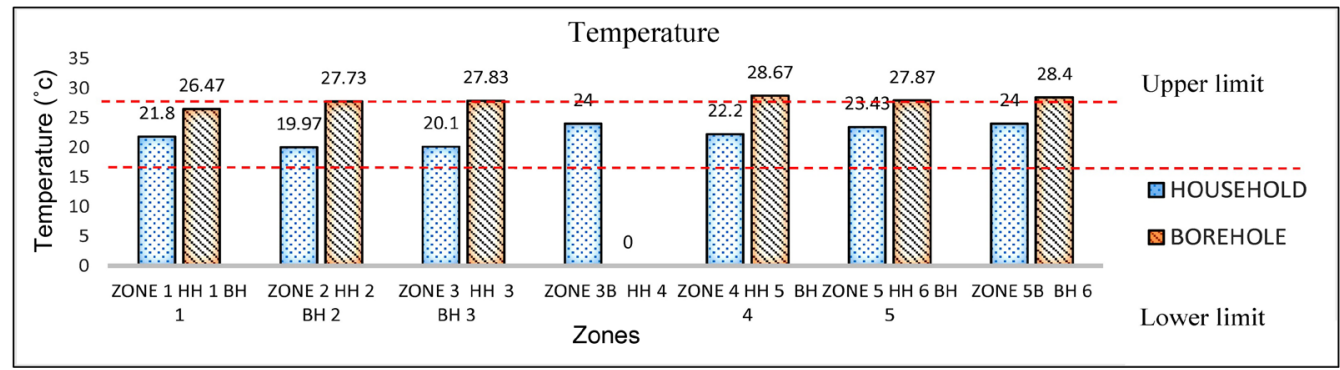

Figure 5. Temperature of drinking water.

\subsection{Physical Examination of Water}

Turbidity is important because it affects both the acceptability of water to consumers, and the selection and efficiency of treatment processes, particularly the efficiency of disinfection with chlorine since it exerts a chlorine demand and protects microorganisms and may also stimulate the growth of bacteria [11]. Figure 6 shows that $100 \%$ of borehole samples indicated high values of 4 NTU close to 5.0 as compared to household water between 0.1 and 0.9 .

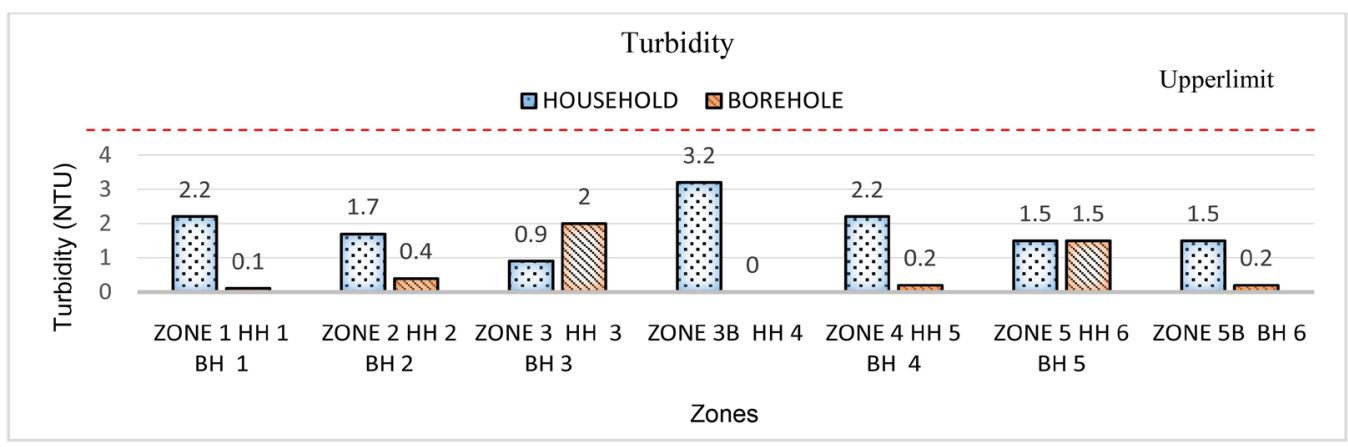

Figure 6. Turbidity of drinking water.

\section{Smell, taste and colour as per water source}

The study reveals that $26.7 \%$ of the respondents indicated that borehole had a foul smell, $12.9 \%$ indicated that networked water supply had a foul smell and $33.3 \%$ indicated that water kiosk source had a foul smell.

Out of $79 \%$ of the respondents who indicated that the taste of the various water sources had taste, $33.3 \%$ of them indicated that borehole water had a taste.

According to guidelines by [9], colour in drinking-water may be due to the presence of coloured organic matter, e.g. humic substances, metals such as iron and manganese, or highly coloured industrial wastes. Drinking-water should be colourless. Out of $86.3 \%$ of respondents who said their source of water was from borehole and networked water supply indicated that the water is clear, $66.7 \%$ indicated that water from kiosk was cloudy/dirty, $25.0 \%$ of water truck supply indicated that the water was cloudy/dirty.

\subsection{Bacteriological Examination of Water Sources for Contamination}

The aim of the bacteriological analysis was to test presence of coliforms which is 
a threat to human health. E. coli is a normal inhabitant of the intestinal tract and is not normally found in fresh water. Therefore, if it is detected in water, it is assumed that there has been faecal contamination of the water.

From Table 1, the study revealed that $100 \%$ boreholes and $30 \%$ of Households within zone had presence of E. coli. However, among all sampled boreholes, BH 5 and $\mathrm{HH} 3$ recorded the highest count of up to 1100 making the water unsatisfactory and highly contaminated. About 75\% of all sampled Households recorded unsatisfactory water quality with $100 \%$ of boreholes recording unsatisfactory water quality as evidenced in Table 2 . This indicates presence of $E$. coli and other faecal coliforms water. $\mathrm{HH} 4, \mathrm{HH} 5$ and $\mathrm{HH} 7$ had nil $E$. coli, hence falling within

Table 1. MPN index of water samples when 3 tubes are used per dilutions $(10 \mathrm{ml}, 1.0 \mathrm{ml}$ and $0.1 \mathrm{ml}$ ) and coliforms identified.

\begin{tabular}{|c|c|c|c|c|c|c|}
\hline $\begin{array}{l}\text { Zone } \\
\text { No. }\end{array}$ & $\begin{array}{l}\text { Source of } \\
\text { water }\end{array}$ & $\begin{array}{c}\text { Place of } \\
\text { collection }\end{array}$ & $\begin{array}{l}\text { Combination of } \\
\text { Positives from } \\
\text { presumptive test }\end{array}$ & $\begin{array}{c}\text { MPN } \\
\text { index/1000 ml }\end{array}$ & Interpretation & $\begin{array}{l}\text { Coliform } \\
\text { isolated }\end{array}$ \\
\hline \multicolumn{7}{|c|}{ Borehole samples } \\
\hline 1 & Borehole & BH 1 & $1-3-2$ & 11 & Unsatisfactory & E. coli \\
\hline 2 & Borehole & BH 2 & $2-0-1$ & 11 & Unsatisfactory & E. coli \\
\hline 3 & Borehole & BH 3 & $3-0-1$ & 39 & Unsatisfactory & E. coli \\
\hline 4 & Borehole & BH 4 & $3-1-1$ & 75 & Unsatisfactory & $\begin{array}{c}\text { E. coli, Proteus } \\
\text { vulgalis }(\mathrm{PV})\end{array}$ \\
\hline \multirow{2}{*}{5} & Borehole & BH 5 & $3-3-2$ & 1100 & Unsatisfactory & E. coli \\
\hline & Borehole & BH 6 & $3-1-0$ & 43 & Unsatisfactory & E. coli \\
\hline \multicolumn{7}{|c|}{ Household samples } \\
\hline 1 & Household & $\mathrm{HH} 1$ & $0-1-0$ & 3 & Satisfactory & None \\
\hline 2 & Household & $\mathrm{HH} 2$ & $0-0-0$ & 0 & Satisfactory & None \\
\hline 3 & Household & HH 3 & $3-3-3$ & 1100 & Unsatisfactory & E. coli \\
\hline 3 & Household & $\mathrm{HH} 4$ & $0-0-0$ & 0 & Satisfactory & None \\
\hline 4 & Household & HH 5 & $0-0-0$ & 0 & Satisfactory & None \\
\hline 5 & Household & HH 6 & $1-0-0$ & 4 & Unsatisfactory & E. coli \\
\hline 5 & Household & $\mathrm{HH} 7$ & $0-0-0$ & 0 & Satisfactory & None \\
\hline \multicolumn{4}{|c|}{ Total number of coliforms isolated } & 2386 coliforms & & \\
\hline
\end{tabular}

Table 2. Quality of water samples.

\begin{tabular}{cccc}
\hline Class & Grade & No. of water samples (total no-13) & Source of water sample \\
\hline I & Satisfactory & 6 & Household-5 \\
& & & Borehole-0 \\
& & 7 & Household-2 \\
II & Unsatisfactory & & Borehole-6 \\
\hline
\end{tabular}


the required WASREB standards of nil Coliforms making their water satisfactory for drinking. Other isolated coliforms in $\mathrm{BH} 4$ included Proteus vulgalis (PV) known to inhabit intestines of human beings and animals also indicating presence of faecal contamination of water.

\section{Water monitoring}

Water monitoring was not recorded in any of the households or boreholes. BH 4 specifically indicated lack of treatment of water due to cost of chlorine as compared to ksh 5 per 20 litres jerry can. They also never submitted samples to public health officers for regular water testing.

\section{Discussion}

The results reveal that Umoja Innercore drinking water from boreholes is not safe for consumption both at source and at the households. This is due to the high level of contamination of boreholes as compared to households which fall within the acceptable ranges. The results of this study agree with other study carried out by [1] which found that $90 \%$ of mineral water supplied to people are unsatisfactory for drinking.

From the chemical analysis, chlorine recorded more than 8.5 meaning that there is more acidity in water hence an indicator of a higher alkalinity. Allowable $\mathrm{pH}$ of drinking water should range between $6.5-8.5$ and majority of the boreholes in this study fall above the upper limit of 8.5. According to a study by [3], chlorination is the second most widely-practiced means of treating water at the community level. There are however concerns about the taste and odour of chlorinated water with some consumers finding it objectionable. This study found that households lack the capacity to measure the required chlorine levels. This is confirmed by [3] that this is probably exacerbated by a tendency to add more than the recommended dose of chlorine.

This study recorded high turbidity values in boreholes compared to households which show a high percentage of suspended particles in water. A study by [11] reported that the more total suspended solids in the water, the higher the turbidity. Total dissolved substances can affect water taste and often indicates a high alkalinity or hardness. Clean drinking water should be clear from all particles that are suspended within. WHO and WASREB give a limit of 5.0 NTU as illustrated in Figure 6. This makes borehole water unsafe for consumption as compared to household water.

E. coli is known to cause diarrhea, abdominal pain, fever and sometimes vomiting. The acceptable standards of $E$. coli in drinking water are nil. In this study high count of upto 1100 in $\mathrm{BH} 5$ and $\mathrm{HH} 3$ was recorded, which is a threat to human health both at a public scale and a household level. This is evidence of faecal contamination showing lack of regular water monitoring for quality. Close proximity of boreholes to shallow septic tanks that are not lined with concrete are a possible cause of faecal contamination. Proteus vulgalis is known to cause Urinary tract infections and therefore if detected in water, the water is consi- 
dered unsafe for human consumption. This agrees with the findings of [1] who found out that of the 10 mineral water samples collected which were unsatisfactory for drinking, 7 samples showed an MPN index of more than 1600/100 $\mathrm{ml}$ of water tested, whereas only 2 among the 5 corporation supplied water showed such high MPN index.

Colour change in water is an indicator of possible mixing of ground water and sewer water from the shallow dug septic tanks or leakage from broken distribution pipes. Iron itself doesn't cause direct harm to health but contains bacteria that feed on it. High metal levels are associated with health cases and are known to cause brain damage and respiratory challenges [3]. This can be observed from results of top 10 over and under 5 which upper respiratory tract diseases are leading in Umoja Innercore. This causes water to have unpleasant taste or colour which is the primary indicator and simplest test of acceptance of water as clean. This can also cause diabetes, stomach problems and nausea [15]. Waters containing coliform bacteria also consistently contained organisms producing hydrogen sulfide (H2S). H2S reacts rapidly with iron to form a black iron sulfide precipitate giving water its colour change.

Though boiling targets living contaminants in water and even reduce them by a considerable amount, the chemicals and metals are heat resistant and cannot be eliminated by boiling. Boiling is also unsustainable due to cost of fuel. According to [3] the most commonly used method of water purification in Kenya is boiling. However, due to overdependence on unsustainable sources of energy such as biomass and the problems associated with their use including indoor air pollution, most households who profess to use this method for purification do not use it consistently leading to consumption of unsafe water [16], in his study, confirms these findings that another commonly used method of purification is biosand filtration which has to be proved an effective, simple, inexpensive and reliable. The advantage of biosand filtration is that it can be locally built, using locally available materials, it is easy to maintain, and does not require any energy input and is relatively inexpensive.

As also reported by [1] nearly one tenth of the city households still drink water directly from taps. Broken water pipelines, overflowing sewage, open defecation, corroded pipelines and inadequate maintenance of old pipe network, whose average age is 50 years, are the primary causes of contamination in household water. This study reports that water coming from $\mathrm{Ng}$ 'ethu is $99 \%$ safe for drinking and lacks any contamination. However, the effect of chlorination done at the supply point may be nullified by the time water reaches households due to reasons given by [1]. All six boreholes which were positive for coliforms, indicates the status of ground water which in turn reflects the activities on the surface. Therefore, [1] confirms that quality of boreholes water can be improved by practicing proper waste disposal, creating storm water drains, controlling sewage spills and avoiding open defecation and chlorination. As also recommended by [17], filtration materials and well screens permits water to enter the 
well from the saturated aquifer, prevents sediment from entering the well, and serves structurally to support the aquifer material. The importance of a proper well screen cannot be overemphasized when considering the efficiency of a well and the log-term cost to its owner. They include

1) Continuous-slot screen is made by winding rolled wire, triangular in cross section, around a circular array of longitudinal rods.

2) Filter Packed Wells providing both filtration and stabilization of the screen and greater porosity, higher hydraulic conductivity, higher yield, reduced entrance velocity, reduced sand pumping, and easier grouting. Filter pack must be chlorinated prior to placing it into the open annulus to insure that contaminants are not introduced into the well during the filter-packing process [17].

Though the sample size is small, the results highlight the poor quality of drinking water available to the residents of Umoja and by large Nairobi residents.

\section{Conclusion}

The study highlights that drinking water leaving the treatment works is of good quality and meeting the standards at $99 \%$ purity levels. Water reaching the residents of Umoja Innercore and by NCWSC is less contaminated as compared to water supplied by various private distributors which is highly contaminated. NCWSC which is responsible for the supply of safe drinking water to Nairobi residents, should be stringent towards safe distribution from storage point to the receiving end through the use of non-corrosive pipelines, replace broken pipelines and plug leakages of sewage pipes for the safe delivery. The longer the water is kept in the network, the less the contamination levels. Shallow boreholes are dug close to septic tanks which are not lined with impermeable materials to prevent contamination of raw water and ground water. Drinking water sources should be tested regularly to determine its microbiological quality to prevent outbreak of enteric diseases. Residents should be educated about the spread of water borne diseases and their control measures.

\section{Recommendations}

Inter estate-bulk treatment and storage provides room for water from NCWSC to be stored. Open spaces to serve as sites for a large underground tank. Water supplied to the bulk storage to be of a higher chlorine concentration to chlorinate the water from the boreholes hence maintaining the quality. Piping to be done from the existing boreholes within Umoja Innercore to ensure they supply clean drinking water to the boreholes and payments remitted to private borehole owners monthly from NCWSC. Water kept within network had less contamination as compared to borehole, therefore encouraging supply through a piped system from bulk storage to households.

Digital water monitoring in residential houses have overhead tanks that store water whenever it's supplied by the NCWSC. The tanks are not monitored 
to check on their cleanliness and the quality of water in terms of smell, colour and taste. Install low power node water sensor nodes and solar-powered sensor node on tanks. This gives a real time reporting on water levels ensuring residents don't seek alternative sources due to unexpected shortage.

Align septic tank walls with concrete and Biosand filtration material are not properly constructed and hence they might allow seepage of faecal matter to ground water. Concrete is impermeable reducing chance of possible contamination of ground water with septic tank water since $E$. coli presence shows faecal matter contamination. Biosand filters use in septic tanks allows for filtration which reduces possible contamination of raw water with ground water.

\section{Acknowledgements}

The authors are grateful for the invaluable support of JKUAT for giving me a fee waiver to do this, masters, staff members from the Department of Architecture, Center for Urban studies (CUSt) and Medical Microbiology (JKUAT) who allowed us to work in the laboratories. Gratitude is also due to the Public Health officers, NCWSC staff, Water production Manager and staff at Ng'ethu treatment works and residents of Umoja Innercore who sacrificed their time to participate in this study and whose contribution has made all this possible.

\section{Conflicts of Interest}

The authors declare no conflicts of interest regarding the publication of this paper.

\section{References}

[1] Malathy, B.R., Sajeev, S.K., Thampy, S. and Guruvayurappan, K. (2017) Bacteriological Analysis of Drinking Water by MPN Method from Chennai, India. Journal of Environment Science, Toxicology and Food Technology, 11, 57-64.

[2] Naidoo, S. and Olaniran, A.O. (2013) Treated Wastewater Effluent as a Source of Microbial Pollution of Surface Water Resources. International Journal of Environmental Research and Public Health, 11, 249-270. https://doi.org/10.3390/ijerph110100249

[3] Nyagwencha, J.M., Kaluli, J.W., Home, P.G. and Murage, H. (2017) Access to Safe Drinking Water and Water-Borne Diseases in Masaba North District, Kenya. JKUAT Annual Scientific Conference, Nairobi, 688-694.

http://journals.jkuat.ac.ke/index.php/jscp\%0Ahttp://hdl.handle.net/123456789/2882

[4] Hassan Rashid, M.A.U., Manzoor, M.M. and Mukhtar, S. (2018) Urbanization and Its Effects on Water Resources: An Exploratory Analysis. Asian Journal of Water, Environment and Pollution, 15, 67-74. https://doi.org/10.3233/AJW-180007

[5] United Nations (2019) Goal 6: Ensure Access to Water and Sanitation for All. https://www.un.org/sustainabledevelopment/water-and-sanitation

[6] UNEP (2009) Kenya-Atlas of Our Changing Environment. Nairobi.

[7] Vidija, P. (2019) Contamination Confirmed: Dirty, Sickening Water Spreads Disease in Three Counties.

https://www.the-star.co.ke/watchdog/2019-03-26-dirty-sickening-water-rocks-three 
-counties

[8] Obosi, O.J. (2011) Public Private Partnerships in the Privatization of Water Service Delivery in Kenya. In: Uhlig, D.U., Ed., Current Issues of Water Management, InTech, Nairobi, 207-231. https://doi.org/10.5772/27996

[9] WASREB (2008) Guidelines on Drinking Water Quality \& Effluent Monitoring. Water Services Regulatory Board, Nairobi.

[10] Mccaffrey, S. (1997) Water Quality Parameters and Indicators. Namoi Catchment Management Authority. New South Wales.

[11] WHO (1997) Guidelines for Drinking-Water Quality Volume 3 Surveillance and Control of Community Supplies. Guidelines for Drinking-Water Quality II WHO Library Cataloguing in Publication Data. 2nd Edition, World Health Organization, Geneva, 1-250.

[12] Piyush, G., Govind, P., Milind, G., Srivastava, D.K. and Misra, B.R. (2014) A Study on the Presence of Faecal Coliforms (E. coli) in Groundwater Samples of Gorakhpur City, India. International Research Journal of Environment Sciences, 3, 9-12.

[13] Sivaranjani, S., Rakshit, A. and Singh, S. (2015) Water Quality Assessment with Water Quality Indices. International Journal of Bioresource Science, 2, 85. https://doi.org/10.5958/2454-9541.2015.00003.1

[14] Ali, W. (1989) Bacterial Examination of Water. Vol. 54, 81-92.

[15] Forstinus, N., Ikechukwu, N., Emenike, M. and Christiana, A. (2015) Water and Waterborne Diseases: A Review. International Journal of Tropical Disease \& Health, 12, 1-14. https://doi.org/10.9734/IJTDH/2016/21895

[16] Duke, W.F., Nordin, R.N. and Baker, D. (2006) The Use and Performance of Biosand Filters in the Artibonite Valley of Haiti: A Field Study of 107 Household. International Electronic Journal of Rural and Remote Health Research, 6, 570-589.

[17] Gleeson, T. (2014) Groundwater and Wells. 2nd Edition, Johnson Screen. St. Paul, Minnesota.

https://blogs.agu.org/waterunderground/2018/10/08/groundwater-and-drought 